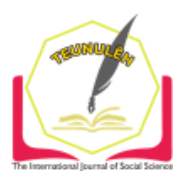

Jurnal Ilmiah Teunuleh

The International Journal of Social Sciences

Vol. 2, Issue. 2, June 2021

E-ISSN: 2746-4393

\title{
ANALYSIS OF THE PHYSICAL CONDITION OF THE ACEH PON RUGBY ALTET 2021
}

\author{
Tuti Sarwita1 \\ Universitas binaBangsaGetsempena \\ tuti.aceh@gmail.com \\ Zulheri Is2 \\ Universitas binaBangsaGetsempena \\ zulheriis6@gmail.com

\section{Septi Hariansyah3} \\ Universitas binaBangsaGetsempena \\ septihariansyah12@gmail.com
}

\begin{abstract}
Rugby is one of the most popular sports abroad. Rugby sport that must have good physical condition for every athlete. The purpose of this study was to determine the level of physical condition of the Aceh PON team rugby athletes. With this type of quantitative descriptive research, the sample in this study was the Putra Pon Aceh Rugby Team as many as 12 athletes. Based on the results of the research on the physical condition test of the endurance level of athletes, the physical condition of the Aceh PON Rugby players was in the "very poor" category of 0\% (0 people), "less" 0\% (0 people), "enough" of 0\% ( 0 people), "good" by 25\% (3 people), and "very good" by 75\% (9 people). Based on the average score, which is 2,800 the physical condition of the Aceh PON Rugby players in the "good" category.
\end{abstract}

Keywords: Physical Condition, Rugby, Atlet 2021

\section{A. Introduction}

Rugby is one of the most popular sports abroad. This sport is popular in European countries, America, and Australia. The parent organization of this sport is the IRB (International Rugby Board). This sport is very universal because it is loved by men, this sport is also loved by women, not only the elderly, young and even children. Since 1990 this sport has been started by women, although previously this sport was only intended for men. 
In Indonesia alone rugby is not quite famous. This is because rugby is a sport that has recently entered Indonesia. However, now there is an official competition under the parent organization of the highest rugby organization in Indonesia, namely PRUI (Persatuan Rugby Union Indonesia). There are several official rugby competitions in Indonesia such as national scale events, namely Jakarta 7's, Jakarta 10's, Nusantara 7's, Jakarta XV, and Sangata 7's as well as international scale events such as Jakarta 10's, Makassar 10's, and Bali 10's. In an official competition required a maturity in playing.

Rugby is a team sport that has three categories: 7's (seven versus seven), 10's (ten versus ten), and $\mathrm{XV}$ (fifteen versus fifteen). This game is played outside the field (outdoor). Although it tends to be a new sport, rugby is starting to develop rapidly in Indonesia, because this game can be played by men, women, children and adults. Rugby is rapidly starting to become one of the favorite sports in the community, because it has begun to be known in all levels of society.

(Suganda, 2017)Rugby in Indonesia is an achievement sport. To achieve achievement requires ability that does not rely on talent alone, but every Rugby athlete must have four aspects of ability quality, namely physical condition, technique, tactics, and mental. Soepartonoin(Sayuti\& Prihanto, 2015)In this team sport an athlete must be able to show individual movements that are smooth, agile and controlled. Getting the highest achievement in the game of Rugby is a dream for every Rugby athlete. If an athlete wants to achieve excellence in Rugby, then the athlete must do intensive training. This exercise is intended to improve and develop the quality of ability to the physical, technical, tactical and mental elements that are very important in the sport of Rugby. Physical condition is a unified whole of components that cannot be separated, both in improving and maintaining it (Sajoto, in .).(Zulheri Is \&Septi Hariansyah, 2020).

The importance of the physical condition of rugby athletes should be realized by the coaches and also the athletes themselves. The coach should always control the physical condition of the athlete, so that it can be detected early if the athlete has a disorder which will affect the performance and appearance of the athlete in the match. The development of the rugby world today has shown a lot of progress, this can be seen from the many competitions or rugby tournaments that are followed, both nationally and internationally.

Full body contact sports, such as rugby, are played continuously or continuously, thus requiring the achievement of a high level of physical fitness. The prerequisites for a successful team are aerobic endurance, anaerobic power, and muscle strength. In eighty 
minutes of play these fitness characteristics can be easily identified as the ability to support, generate speed and acceleration at random intervals and to generate controlled strength and power with the aim of gaining an advantage in the first, second, and concurrent phases.(Burgers et al., 2020). More according to Sajoto(Zulheri Is \& Septi Hariansyah, 2020)there are 10 kinds of components of physical condition, among which are: (1) strength (strength); (2) endurance (endurance); (3) muscle power (muscular power); (4) speed (speed); (5) bending strength (flexibility); (6) agility (agility); (7) coordination (coordination); (8) balance (balance); (9) accuracy (accuracy); (10) reaction (reaction).

Every coach must improve and develop the physical condition of his athletes. If a rugby athlete is to achieve an optimal performance, he must have complete physical, technical, mental development and champion maturity. Physical condition will decrease faster than increase if no exercise is given at all(Dawud \& Hariyanto, 2020). Factors that affect physical conditions include; food and nutrition, sleep and rest factors, healthy living habits, environmental factors, environmental factors and exercise, and others. So, in order to have the ability to have a good physical condition, one must pay attention to these factors.

Rugby athletes are required to have good physical condition because they are required to be able to play or compete for 2 (two) rounds ( $2 \times 40$ minutes). Rugby athletes in defense or attack must face a hard collision (body collision), or have to move, do line outs, scrums, and rugs, and run at full speed or agility / dodge in avoiding opponents. The benefit of physical conditions for rugby is that athletes can play with good stamina during matches. Because in a rugby match both teams play for 80 minutes. With the size of the field and the length of the match, rugby athletes must be able to manage energy so that it is not drained in the first round. A rugby athlete must have good endurance. Rugby matches tend to be long, therefore on average each athlete uses the energy requirements of general endurance or aerobic endurance. This element of physical condition is needed by rugby athletes in order to play well(Fuller et al., 2017). In addition to being in excellent physical condition, to become a rugby athlete, one must also have good technique. Rugby playing techniques consist of: (1) kicking, (2) ruck, (3) tackling, (4) line out, (5) scrum, (6) maul, (7) passing, (8) footwork/step. A rugby athlete must have and master the good playing techniques needed when attacking and controlling the ball as well as when defending. The basic technical ability of rugby athletes is closely related to the ability to coordinate physical movements. The basic skills of playing rugby can be 
developed through regular training. In order to achieve optimal performance, support for physical improvement and athlete talent is also needed.

Rugby Sport is a sport that has been very developed in parts of Europe and the world, but in Aceh Rugby Sport is relatively new and very young in age, this sport only entered Aceh around 2016 therefore this sport is still not familiar to the people of Aceh and especially children -child. Although the sport of Rugby is categorized as new in Aceh, but Aceh has been able to directly compete with other regions regarding the achievements of its athletes, this is proven by the success of 5 Acehnese children who have been able to represent Aceh to be able to strengthen Indonesia in the 2019 Philippine Sea Game. This sport in Aceh has succeeded in producing talented athletes, This can be seen from the ability of the Aceh Rugby Athlete Team, which has been able to compete at the national level by being able to enter the top 5 in the Pre-PON selection in PAPUA in 2021. It is a very good achievement for a new sport branch in a very short time to be able to penetrate the national level.

Therefore, this sport needs to be introduced to the wider community so that it can awaken prospective athletes in the future and be able to continue the struggle of their brothers and sisters in the future in achieving Aceh's proud achievements through the sport of Rugby. This sport of rugby is a sport that is cheap and lively, fiber is also very easy and fun. This rugby game is played using a soccer field with a total of 7 players in one team, what distinguishes this game from football is football, the rugby ball is oval, the rugby game is played by hand by scoring points brought run to the opposing team's goal. This game is also easy to rely on only compactness and speed. This sport is also safe to be played by all circles because besides being easy and this sport is also cheap. So that in this pandemic period it can be a new alternative to be able to maintain physical fitness by playing this game.

So far, the aceh rugby team has achieved many achievements, seen from the sport of rugby, which is one of the sports that just emerged in aceh in 2019, the achievements obtained cannot be separated from the athlete's physical condition factor. During the Covid-19 pandemic, sports activities for the Aceh Rugby team were limited to avoid the spread of the virus that swept across the country. Based on the 2020 Ministry Circular regarding the prevention of the spread of covid 19. Especially in the sport of rugby, training activities must also be adjusted to government conditions and regulations so that the training activities of the Aceh rugby team are not optimal. 


\section{B. Method}

This research is a quantitative descriptive study, which is a research method used to describe existing phenomena, which are currently or in the past. (Sugiono, 2014). Who became the research subject of all Aceh Rugby PON athletes. With the technique of collecting data, the physical condition test is an endurance test.

\section{Finding and Discussion}

The results of this study were obtained from physical condition tests with test participants of the Aceh PON rugby team players. The physical condition test consists of several items including a test of explosive power (power), a test of speed (speed), a test of agility (agility), an endurance test (endurance), and a test of strength (strength). There is also a test used in this study, namely the endurance test. From the detailed research results as follows:

Table 1. Frequency Distribution of Physical Condition Endurance Test for Aceh PON Rugby Players

\begin{tabular}{llccc}
\hline No. & interval & Category & Frequency & $\%$ \\
\hline 1. & $>2,800$ meters & Very good & 9 & $75 \%$ \\
2. $2,400-2,800$ meters & Good & 3 & $25 \%$ \\
3. $2,200-2,399$ meters & Enough & 0 & $0 \%$ \\
4. $1,600-2,199$ meters & Less & 0 & $0 \%$ \\
5. $<1,600$ meters & Very less & 0 & $0 \%$ \\
amount & & 12 & $100 \%$ \\
\hline
\end{tabular}

Source: 2021 research results

Based on the table above shows that the physical condition of the Aceh PON Rugby players are in the "very poor" category of 0\% (0 people), "less" 0\% (0 people), "enough" 0\% (0 people), " good" by 25\% (3 people), and "very good" by 75\% (9 people). Based on the average score, which is 2,800 the physical condition of the Aceh PON Rugby players in the "good" category. 


\section{Discussion}

This study aims to determine the physical condition of Aceh PON Rugby players, which consists of endurance tests. The results of the study show that the overall physical condition of the Aceh PON Rugby players is explained as follows:

The physical condition of Aceh PON Rugby players is in the "very poor" category of 0\% (0 people), "less" 0\% (0 people), "enough" 0\% (0 people), "good" 25\% ( 3 people), and "very good" by $75 \%$ (9 people). Based on the average score, which is 2,800 the physical condition of the Aceh PON Rugby players in the "good" category.

Physical condition is an important thing that forms the basis for developing techniques, tactics, and strategies in playing rugby. The controlled exercise pattern of ACEH PON rugby players greatly influences the results of physical condition tests. The rugby status of PON ACEH has athletes who have joined the rugby national team in the past year.

In this study, the athletes' physical condition tests focused on endurance tests. A heart and lung endurance test is performed to measure the ability to use the heart and lungs effectively and efficiently. Its function is to supply oxygen and energy when doing a physical activity. This test is generally done by running 12 minutes and can be interspersed with walking, if you are not strong enough to run continuously.

A player who is in good physical condition has several advantages, including being able to complete a training program without significant obstacles, having more stamina or not getting tired easily during training or matches, and being able to learn relatively difficult skills with ease. Excellent physical condition is needed by an athlete to achieve higher achievements. With this research, it is hoped that coaches and athletes can find out the status of the physical condition of athletes or players of PON ACEH Rugby, so that coaches and athletes can arrange and arrange retraining schedules to improve discipline and participation of ACEH PON Rugby players during training. This is very important because it is to maintain and improve the physical condition of athletes so that they can achieve peak performance.

\section{Conclusions}

Based on the results of the study, it can be concluded that from the results of the endurance test, the physical condition of the Aceh rugby athletes was in the very good category, 9 athletes with a percentage of 75\%, and 3 athletes with a percentage of 25\%, out of a total of 12 athletes. 
Analysis of the Physical Condition of the Aceh PON Rugby Atlet 2021

\section{Suggestion}

Based on the conclusions of the research above, there are several suggestions that can be submitted, namely:

1. The results of the study can be used as input and evaluation for coaches, in preparing and compiling the next training program for Aceh PON Rugby players.

2. For further researchers to add research subjects with a larger scope and with more varied research models.

3. Rugby players should follow the existing training schedule and do exercises outside the training schedule as well as maintain in terms of training discipline and food intake in order to further support their physical condition for those who are lacking.

\section{Bibliography}

Burger, N., Lambert, M., \& Hendricks, S. (2020). Lay of The Land: Narrative Synthesis of Tackle Research in Rugby Union and Rugby Sevens. British Journal of Sport Medicine, 6(1). doi:10.1136/bmjsem-2019-000645

Dawud, V. W., \& Hariyanto, E. (2020). Survey on Physical Condition of Soccer Players U 17. Survei Kondisi Fisik Pemain Sepakbola U 17, 2(4), 224-231.

Fuller, C. W., Taylor, A., Kemp, S. P., \& Raftery, M. (2017). Rugby World Cup 2015: World Rugby Injury Surveillance Study. British Journal of Sports Medicine, 5(1). doi:10.1136/bjsports-2016-096275

Is, Z., \& Hariansyah, S. (2020). Hubungan Daya Tahan Jantung Paru Dengan Keterampilan Bermain Futsal Pada Klub Satoe Atjeh Futsal Academy. Jurnal Penjaskesrek, 7(1), 175-187. doi:10.46244/penjaskesrek.v7i1.11016

Nurhastuti. (2019). Profile of Physical Condition of UNY Rugby Players In 2018.

Sayuti, P., \& Prihanto, J. B. (2015). Penerapan Media Audio Visual Terhadap Hasil Belajar Teknik Passing Kaki Bagian Dalam Pada Permainan Sepak Bola. Jurnal Pendidikan Olahraga dan Kesehatan, 3(1), 71-74.

Suganda, M. A. (2017). Pengaruh Latihan Lingkaran Pinball Tehadap Ketepatan Passing Datar Dalam Permainan Sepakbola Pada Siswa Ekstrakurikuler di SMK YPS Prabumulih. 16(1), 57-61. doi:10.24114/jik.v16i1.6452

Sugiyono. (2014). Educational Research Methods Quantitative, Qualitative And R\&D Approaches. Bandung: Alfabeta. 